\title{
Heterologous expression of Pycnoporus cinnabarinus cellobiose dehydrogenase in Pichia pastoris and involvement in saccharification processes
}

Mathieu Bey ${ }^{1,2^{*}}$, Jean-Guy Berrin ${ }^{1,2}$, Laetitia Poidevin ${ }^{1,2,3}$ and Jean-Claude Sigoillot ${ }^{1,2}$

\begin{abstract}
Background: Cellobiose dehydrogenase $(\mathrm{CDH})$ is an extracellular hemoflavoenzyme produced by lignocellulosedegrading fungi including Pycnoporus cinnabarinus. We investigated the cellulolytic system of $P$. cinnabarinus, focusing on the involvement of $\mathrm{CDH}$ in the deconstruction of lignocellulosic biomass.

Results: First, $P$. cinnabarinus growth conditions were optimized for $\mathrm{CDH}$ production. Following growth under cellulolytic conditions, the main components secreted were cellulases, xylanases and CDH. To investigate the contribution of $P$. cinnabarinus secretome in saccharification processes, the Trichoderma reesei enzymatic cocktail was supplemented with the $P$. cinnabarinus secretome. A significant enhancement of the degradation of wheat straw was observed with (i) the production of a large amount of gluconic acid, (ii) increased hemicellulose degradation, and (iii) increased overall degradation of the lignocellulosic material. P. cinnabarinus CDH was heterologously expressed in Pichia pastoris to obtain large amounts of pure enzyme. In a bioreactor, the recombinant $\mathrm{CDH}(\mathrm{rCDH})$ expression level reached $7800 \mathrm{U} / \mathrm{L}$. $\mathrm{rCDH}$ exhibited values of biochemical parameters similar to those of the natural enzyme, and was able to bind cellulose despite the absence of a carbohydratebinding module (CBM). Following supplementation of purified $r C D H$ to T. reesei enzymatic cocktail, formation of gluconic acid and increased hemicellulose degradation were observed, thus confirming the previous results observed with $P$. cinnabarinus secretome.
\end{abstract}

Conclusions: We demonstrate that $\mathrm{CDH}$ offers an attractive tool for saccharification process enhancement due to gluconic acid production from raw lignocellulosic material.

Keywords: White-rot fungi, CDH, gluconic acid, lignocellulose, biomass, saccharification

\section{Background}

In natural environments, cellulolytic microorganisms secrete enzymes that function synergistically, in association with the microorganism or independently. Although it is not fully known how many enzymes are involved in cell wall deconstruction, three general categories of enzymes are considered necessary to hydrolyze native cell wall materials: cellulases, hemicellulases and accessory enzymes such as hemicellulose debranching

\footnotetext{
* Correspondence: mathieu.bey@esil.univmed.fr

${ }^{1}$ INRA, UMR1163 BCF, 163 avenue de Luminy, 13288 Marseille, France Full list of author information is available at the end of the article
}

enzymes, phenolic acid esterase, and possibly lignindegrading and modifying enzymes [1].

The main industrial source of cellulases and hemicellulases is the mesophilic soft-rot fungus T. reesei (teleomorph Hypocrea jecorina), valued for the high protein secretion capacity of its mutant strains obtained by random mutagenesis (producing up to $100 \mathrm{~g}$ of extracellular protein per liter of culture) $[2,3]$.

Among fungal classes, basidiomycetes are known to be efficient degraders of cellulose, many species growing on dead wood or litter. The lignocellulolytic system of basidiomycetes has been studied intensively in the last decades. Genome sequencing and proteomic tools are often

\section{Biomed Central}

(c) 2011 Bey et al; licensee BioMed Central Ltd. This is an Open Access article distributed under the terms of the Creative Commons Attribution License (http://creativecommons.org/licenses/by/2.0), which permits unrestricted use, distribution, and reproduction in any medium, provided the original work is properly cited. 
used, but the cellulolytic system is still not completely understood, especially the oxidative part of this system $[4,5]$.

Cellobiose dehydrogenases (CDH; E.C. 1.1.99.18; cellobiose: [acceptor] 1-oxidoreductase) are extracellular fungal hemoflavoenzymes produced by many white-rot fungi including Trametes versicolor, Phanerochaete chrysosporium, Ceriporiopsis subvermispora and P. cinnabarinus [6-9]. $\mathrm{CDH}$ are also produced by the brown-rot fungus Coniophora puteana [10] and the soft-rot fungus Humicola insolens [11]. More recently, CDH from the ascomycetes Myriococcum thermophilum [12] and Neurospora crassa [13] were cloned and successfully expressed in Pichia pastoris. $\mathrm{CDH}$ are monomeric enzymes carrying two prosthetic groups, a heme and a flavin domain. The heme-binding domain in the $\mathrm{N}$ terminal position contains a cytochrome b-type heme which presents an unusual heme binding by Met/His ligation [14]. The flavin domain in C-terminal binds FAD non-covalently and is classified as a member of the glucose-methanol-choline family of oxidoreductases. These two regions are separated by a Thr-Ser-rich long linker region [15]. The flavoprotein domain of $\mathrm{CDH}$ catalyzes two-electron oxidation of cellobiose and more generally cellodextrines, mannodextrines and lactose to corresponding lactones [16] using electron acceptors such as dioxygen, quinones, phenoxyradicals and others [17-19]. Also, one-electron transfer occurs. Heme is implicated in one internal electron transfer to FAD or another electron acceptor such as $\mathrm{Fe}^{3+}[20,21]$.

Among oxidoreductases, laccases have been the most intensively studied, while CDHs are less well-researched. To date, thirteen CDHs have been characterised $(P$. chrysosporium [7], Sclerotium (Athelia) rolfsii [22], Monilia sp. [23], T. versicolor [9], Trametes hirsuta [24], P. cinnabarinus [25], Schizophyllum commune [26], C. subvermispora [6], Sporotrichum thermophilum [27], C. puteana [10], Chaetomium sp. [28], M. thermophillum [12], Termitomyces clipeatus [29], H. insolens [11], Grifola frondosa [30] and N. crassa [13]).

Although the role of CDHs is still unclear, it is established that $\mathrm{CDHs}$ are produced in cellulolytic conditions and are involved in cellulose and lignin degradation. CDHs have been shown to bind cellulose in different ways depending on species: a long aromatic-rich region for $P$. chrysosporium [31] or a cellulose-binding domain for ascomycetes and soft-rot fungi, similar to that observed for cellulases [32]. Their involvement in many reactions has been demonstrated, e.g. reduction of quinones [33,34], inhibition of phenol radical repolymerization [35,20], production of hydrogen peroxide $[36,37]$ and one of the most often cited reactions, the production of hydroxyl radicals by a Fenton-type reaction, which may participate in the degradation of cellulose, lignin and xylan [38]. CDHs are known to enhance the action of cellulases on crystalline cellulose $[39,40]$ and also to degrade wood components, but their role in complex lignocellulosic substrate degradation has never been investigated.

Here we examined the cellulolytic system of $P$. cinnabarinus and the involvement of $\mathrm{CDH}$ therein. Given its relevance to saccharification processes, we heterologously expressed the P. cinnabarinus $\mathrm{CDH}$ in Pichia pastoris. The recombinant enzyme was thoroughly characterized and assessed for its ability to degrade natural substrate as a supplement to commercial Trichoderma reesei cocktail.

\section{Results}

Production and characterization of $P$. cinnabarinus ss 3 secretome in cellulolytic conditions

$\mathrm{CDH}$ is produced by $P$. cinnabarinus when cellulose is added to the culture medium. The best production (355 $\mathrm{U} / \mathrm{L}$ ) appeared after 10 days of cultivation when cellulose was used as sole carbon source. To understand the role of $\mathrm{CDH}$ when secreted in cellulolytic conditions, we characterized the $P$. cinnabarinus secretome after 11 days of growth.

Main enzymatic activities present in $P$. cinnabarinus secretome in cellulolytic conditions were measured by assay on a range of substrates (Table 1). No significant laccase or peroxidase activities were detected under our experimental conditions. However, P. cinnabarinus secretome contained enzymes able to hydrolyze a broad range of polysaccharides. Significant levels of activities towards pNP-glucose, CMC and pNP-cellobiose were detected, corresponding to $\beta$-glucosidase $(0.35 \mathrm{U} / \mathrm{mg})$, endoglucanase $(0.55 \mathrm{U} / \mathrm{mg})$ and cellobiohydrolase $(0.32$

Table 1 Lignocellulose-degrading enzyme activities measured in P.cinnabarinus secretome

\begin{tabular}{|c|c|c|}
\hline Type of activity & Substrate & Activity (U/mg) \\
\hline $\mathrm{CDH}$ & Cellobiose & 0.53 \\
\hline Laccase & ABTS & $n^{a}$ \\
\hline Glucose oxidase & Glucose & $\mathrm{nd}^{\mathrm{a}}$ \\
\hline Manganese peroxidase & Vanillyl acetone & $n^{a}$ \\
\hline Lignin peroxidase & Veratryl alcohol & $\mathrm{nd}^{\mathrm{a}}$ \\
\hline$\beta$-Glucosidase & pNP-glucose & $0.35 \pm 0.00$ \\
\hline Endoglucanase & CMC & $0.55 \pm 0.00$ \\
\hline Cellobiohydrolase & pNP-Cellobiose & $0.32 \pm 0.00$ \\
\hline$\beta$-Xylosidase & pNP-Xylose & $0.01 \pm 0.00$ \\
\hline Endo-xylanase & Low viscosity arabinoxylan & $2.03 \pm 0.08$ \\
\hline$\beta$-Mannosidase & pNP-Mannose & $\mathrm{nd}^{\mathrm{a}}$ \\
\hline Endo-mannanase & Galactomannan & $2.03 \pm 0.11$ \\
\hline Pectinase & Pectin & $0.45 \pm 0.02$ \\
\hline$\alpha$-Galactosidase & pNP-Galactose & $0.85 \pm 0.00$ \\
\hline
\end{tabular}

Results are expressed in $\mathrm{U} / \mathrm{mg}$ of total proteins.

a no activity detected 
$\mathrm{U} / \mathrm{mg})$. A variety of hemicellulases were also identified in $P$. cinnabarinus secretome. The two main endo-glycosidase activities were present corresponding to endomannanase and endo-xylanase with about $2 \mathrm{U} / \mathrm{mg}$. Hemicellulase exoglycosidase enzymes were detected to a lesser extent: $0.85 \mathrm{U} / \mathrm{mg}$ of $\alpha$-galactosidase and 0.01 $\mathrm{U} / \mathrm{mg}$ of $\beta$-xylosidase were measured.

Zymogram assays were performed on the culture extract of $P$. cinnabarinus to give insight into the number of isoforms present for the main enzymatic activities previously measured.

SDS-PAGE of $P$. cinnabarinus (Figure 1, lane 2) grown in cellulolytic conditions presented two main differences when compared with reference culture supernatant grown in non-cellulolytic conditions: (i) the presence of a band around $100 \mathrm{kDa}$, attributable to $\mathrm{CDH}$ and (ii) the absence of $70 \mathrm{kDa}$ band corresponding to laccase. Confirmation by the zymogram technique showed the DCPIP decoloration by the $100 \mathrm{kDa}$ band corresponding to $\mathrm{CDH}$ activity (Figure 1, lane 3). Oxidation of ABTS occurred at around $50 \mathrm{kDa}$ (Figure 1, lane 4) and could not be attributed to laccase, which has a molecular mass of $70 \mathrm{kDa}$. The xylanase zymogram (Figure 1, lane 5) demonstrated the presence of a weak activity at $50 \mathrm{kDa}$ corresponding to the results previously described [41]. CMCase zymogram (Figure 1, lane 6) showed at least five bands with the brightest one at $25 \mathrm{kDa}$. For mannanase activity (Figure 1, lane 7), some bands were represented around one major band at $60 \mathrm{kDa}$.

\section{$P$. cinnabarinus $\mathrm{CDH}$ sequence analysis}

Based on P. cinnabarinus ss 3 cdh sequence, primers were designed to clone the $c d h$ gene starting from 4-day-old culture induced with cellulose. The $c d h$ sequence of 2310 bp was compared with available $c d h$ sequences. Nucleotide sequence analysis showed $97 \%$ identity between $c d h$ of $P$. cinnabarinus I-937 described by Moukha et al. [8] and the $c d h$ from $P$. cinnabarinus ss3, a monokaryotic strain isolated from the fruit-like structure of $P$. cinnabarinus I-937, a wild-type dikaryotic strain. These observed differences in the nucleotide sequence resulted in eight amino acid differences at positions 96 (Ala $\rightarrow-$ Glu), 331 (Arg $\rightarrow$ Ser), 354 (Ala $\rightarrow$ Thr), 357 (Asn $\rightarrow$ Lys), $386(\mathrm{Tyr} \rightarrow$ Ser $), 426$ (Tyr $\rightarrow$ Phe) and 495 (Gln $\rightarrow$ Glu). Comparison with $T$. versicolor $\mathrm{CDH}$ and $P$. chrysosporium $\mathrm{CDH}$ resulted in amino acid sequence identities of $77 \%$ and $70 \%$, respectively. $P$. cinnabarinus $\mathrm{CDH}$ amino acid sequence exhibited conserved regions with GMC oxidoreductase [42] conserved domain. The linker region rich in Thr-Ser (from position 182 to position 215), the FAD binding site and the Met/His ligands for heme fixation were also identified. Interestingly, the Thr-Ser region was also rich in Pro (28\% Thr, 25\% Pro, 13\% Ser). Analysis of the gene encoding the $\mathrm{CDH}$ from $P$. cinnabarinus has shown high sequence homology with $c d h$ from class I. Indeed, phylogenetic analysis of $c d h$ genes revealed two major classes [42]. The class I $c d h$ genes are found only in basidiomycetes while the class II contain more complex ascomycetes CDHs, that sometimes present a family 1 carbohydrate-binding module (CBM) at the C-terminal position. Emergence of a third class of CDHs in ascomycetes fungi was recently reported [32].

\section{Heterologous expression of $\mathrm{CDH}$ in $P$. pastoris}

The coding sequence of $c d h$ was inserted into the $P$. pastoris expression vector in frame with sequences

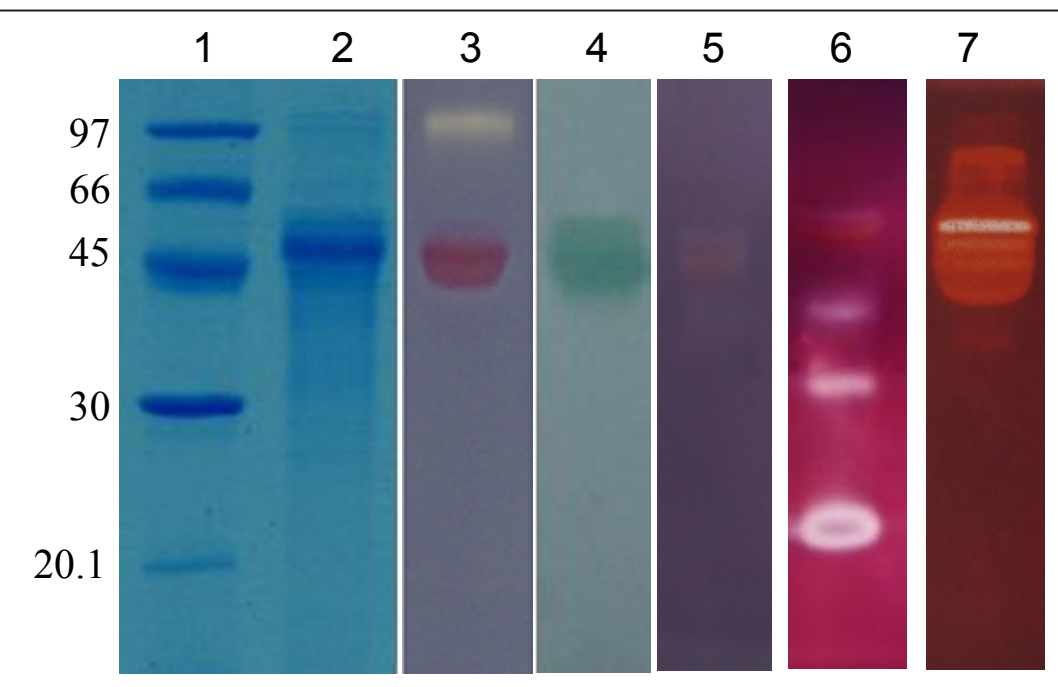

Figure 1 SDS-PAGE and zymogram on the supernatant of $P$. cinnabarinus ss 3 grown in cellulolytic conditions. 1, pre-stained molecular weight marker; 2, SDS-PAGE with $10 \mu \mathrm{g}$ of protein supernatant after ultrafiltration step; 3, CDH zymogram; 4, zymogram with ABTS; 5, soluble xylan birchwood (xylanase) zymogram; 6, CMC (endoglucanase) zymogram and 7, locust bean gum (mannanase) zymogram. 
encoding the yeast $\alpha$-factor secretion peptide and a (His) 6 tag located at the $\mathrm{C}$ terminus. The recombinant gene was then introduced into the Pichia genome under the control of the methanol-inducible promoter. Multicopy transformants were screened to select a clone that exhibited satisfactory levels of production. $\mathrm{CDH}$ activity was successfully detected in the supernatant after induction, indicating correct processing of the $\alpha$-factor signal sequence.

A maximum activity of $1176 \mathrm{U} / \mathrm{L}$ was observed after 4 days of induction, and this clone was chosen for this study. To scale up enzyme production, we optimized $\mathrm{CDH}$ expression in a 1 liter bioreactor with the best-performing clone of $P$. pastoris. The recombinant $\mathrm{CDH}$ was secreted at high levels, reaching $7800 \mathrm{U} / \mathrm{L}$. Recombinant $\mathrm{CDH}$ was purified after 4 days of induction, taking advantage of the (His) $)_{6}$ tag. Also, only trace amounts of endogenous proteins were present in the culture supernatant of the transformant secreting $\mathrm{CDH}$. The purified enzyme exhibited a specific activity of $22.2 \mathrm{U} / \mathrm{mg}$.

\section{Biochemical characterization of $\mathrm{rCDH}$}

Recombinant $\mathrm{CDH}$ was purified to homogeneity, i.e. one major band displaying a relative molecular weight around $110 \mathrm{kDa}$ (Figure 2, lane 2) appeared on SDSPAGE. Western blot analysis (Figure 2, lane 4) confirmed the presence of $\mathrm{CDH}$ at $110 \mathrm{kDa}$.

Zymogram analysis of $\mathrm{CDH}$ activity revealed active bands on the gel corresponding to 70 and $110 \mathrm{kDa}$ (Figure 2, lane 3). Deglycosylation (Figure 2, lane 5) of $\mathrm{CDH}$ showed enhanced degradation between the two enzyme moieties and a loss of approximately $10 \mathrm{kDa}$. Following papain cleavage of $\mathrm{CDH}$, a band corresponding to the
FAD-containing moieties was observed on SDS-PAGE (Figure 2, lane 6). The heme-containing domain was not seen after staining, probably owing to the weak presence of aromatic residues [43].

Binding studies of $\mathrm{CDH}$ confirmed the ability of the enzyme to bind cellulose without the presence of a cellulose-binding domain. Dissociation constant $\left(K_{d}\right)$ and binding capacities $\left(B_{\max }\right)$ of $\mathrm{CDH}$ were determined and were respectively $0.064 \mu \mathrm{M}$ and $0.2 \mu \mathrm{mol} / \mathrm{g}$ of Avicel (Figure 3).

When DCPIP is used as electron acceptor, the optimal temperature for $\mathrm{CDH}$ is $70^{\circ} \mathrm{C}$. The recombinant enzyme displayed activity over a wide range of temperatures, $16 \%$ of residual activity at $10^{\circ} \mathrm{C}$ and $55 \%$ of residual activity at $80^{\circ} \mathrm{C}$ (Figure $4 \mathrm{~A}$ ).

After incubation of $\mathrm{CDH}$ at 45,50 and $55^{\circ} \mathrm{C}$ for $33 \mathrm{~h}$, residual enzyme activity was $90 \%, 80 \%$ and $63 \%$ respectively. However, $\mathrm{CDH}$ was not stable at $65^{\circ} \mathrm{C}$, with only $15 \%$ of activity remaining after $9 \mathrm{~h}$ (Figure $4 \mathrm{C}$ ). The optimal $\mathrm{pH}$ for recombinant $\mathrm{CDH}$ (Figure 4A) was $\mathrm{pH}$ 4.5. The recombinant $\mathrm{CDH}$ had $V_{\max }=22.2 \mathrm{U} / \mathrm{mg}$ and $K_{M}=35.5 \mu \mathrm{M}$ for cellobiose with DCPIP as electron acceptor. Using cyt c as electron acceptor, we found $V_{\text {max }}=3.9 \mathrm{U} / \mathrm{mg}$ and $K_{M}=14.7 \mu \mathrm{M}$ (Table 2).

\section{Effect of $\mathrm{CDH}$ on the saccharification of wheat straw}

The range of lignocellulosic enzymes found in the supernatant of $P$. cinnabarinus makes it a candidate for supplementation of the $T$. reesei cocktail for saccharification of wheat straw. We thus set out to compare the efficiency of the $P$. cinnabarinus supernatant with the purified $\mathrm{rCDH}$ for supplementation of industrial cocktails.

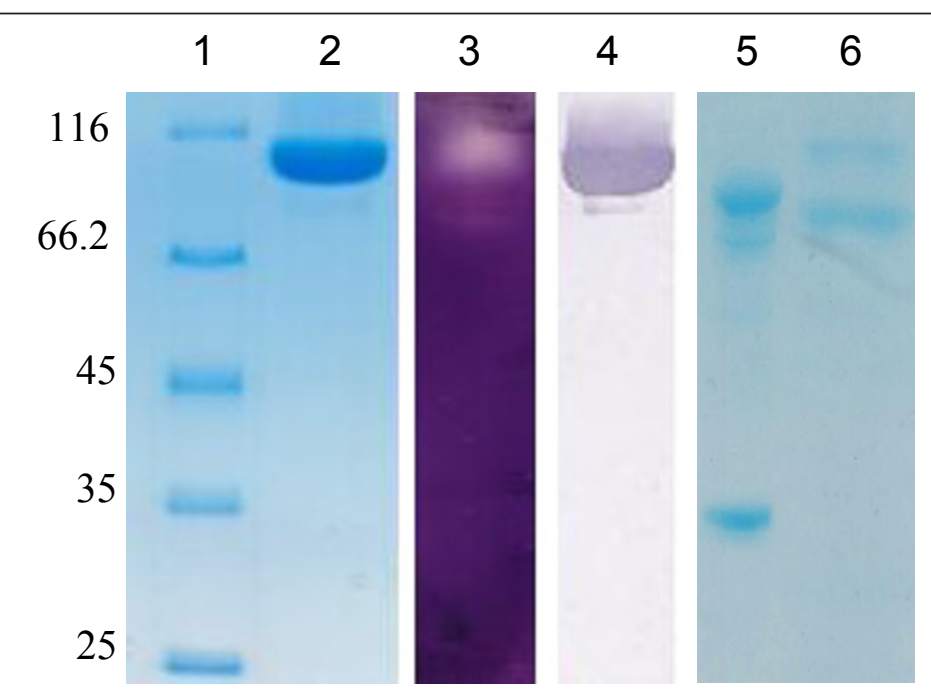

Figure 2 SDS-PAGE, zymogram, immunoblot analysis, deglycosylation and cleavage by papain of purified recombinant rCDH. 1, prestained molecular weight marker; 2, $10 \mu \mathrm{g}$ of purified $\mathrm{CDH} ; 3, \mathrm{CDH}$ zymogram on the sample 2; 4, Western blot analysis using anti-His antibodies; 5, CDH deglycosylated; 6, CDH digested by papain. 


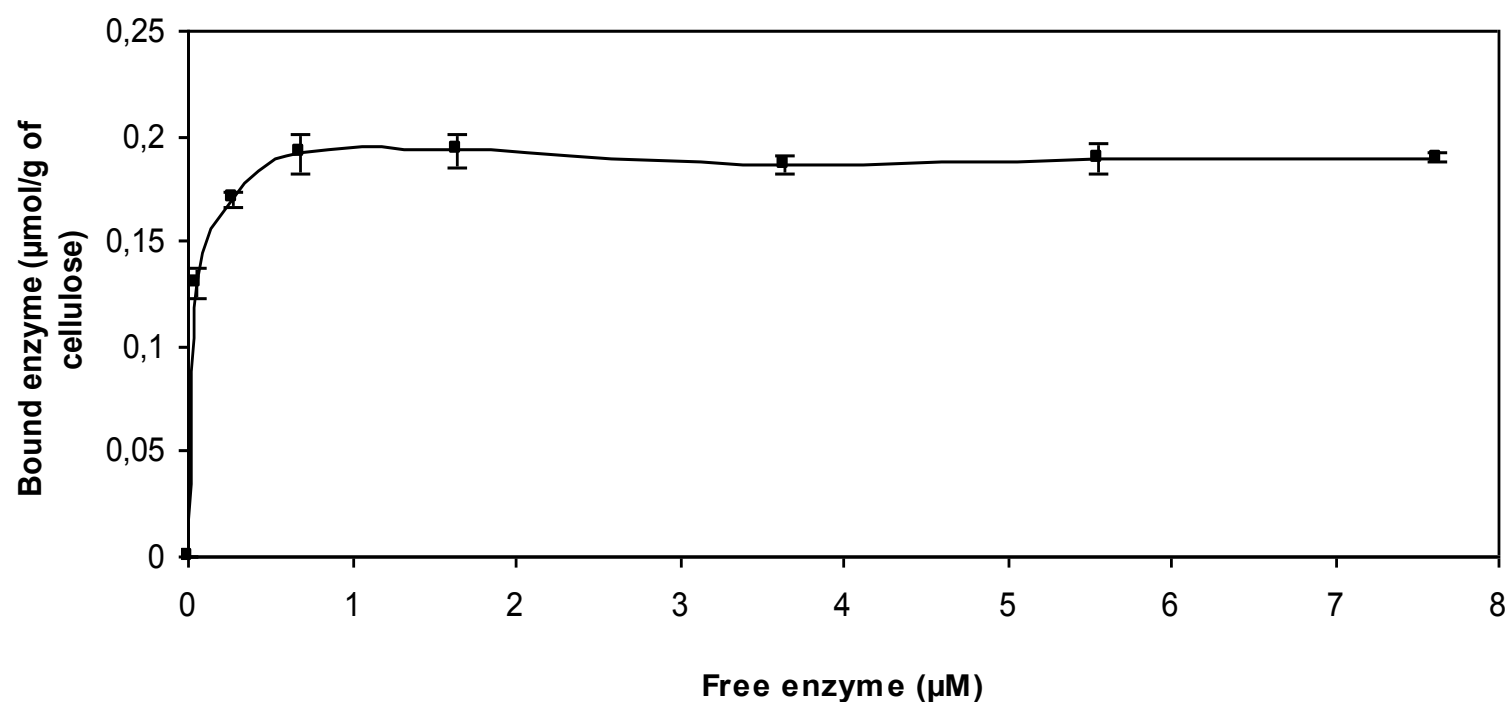

Figure 3 Kinetics of the binding of $\mathbf{r C D H}$. Experiments were performed on Avicel at $30^{\circ} \mathrm{C}, \mathrm{pH} 4.5$. Error bars indicate standard deviations from triplicate measures performed independently.

The T. reesei cocktail supplemented with $\beta$-glucosidase was used as reference. Addition of $P$. cinnabarinus secretome $(10,20$ and $40 \mathrm{U}$ of $\mathrm{CDH})$ or pure $\mathrm{rCDH}(10$ and $20 \mathrm{U}$ ) gave similar results (Figure 5 and Figure 6). DNS assays were used to measure reducing ends of sugars released after saccharification. Supplementation with purified $\mathrm{rCDH}$ or secretome containing $\mathrm{CDH}$ showed less response on DNS titration than control with cocktails (Figure 5). However, overall hydrolysis was increased by addition of $\mathrm{CDH}$, with the production of large amounts of gluconic acid, from 5 to $100 \mathrm{mg}$ per g of wheat straw, compared with control. Also, greater yields of xylose, galactose and arabinose, which increased respectively from 35 to $44,1.9$ to 4 and 9.5 to $13.5 \mathrm{mg} / \mathrm{g}$ of wheat straw were observed with addition of $10 \mathrm{U}$ of $\mathrm{CDH}$ (Figure 6A). Production of gluconic acid by $\mathrm{CDH}$ can be explained by the formation of cellobionolactone following by its spontaneous hydrolysis in cellobionic acid. This last compound can be cleaved by $\beta$-glucosidase into glucose and gluconic acid. Experiments were performed on Dionex (data not shown).

To confirm the strong production of gluconic acid, purified recombinant $\mathrm{CDH}$ was used to supplement the $T$. reesei and $A$. niger cocktails. The effect on wheat straw was comparable to that obtained with $P$. cinnabarinus secretome (Figure 6B). Also, supplementation with $10 \mathrm{U}$ of $\mathrm{rCDH}$ did not affect the yield of glucose, increased hemicellulose yield and resulted in the formation of gluconic acid in large amounts.

\section{Discussion}

In the last few decades the white-rot fungus $P$. cinnabarinus has been studied for its ligninolytic system, which is based on phenoloxidases such as laccases, without the presence of peroxidases [44]. This system, and especially laccase, has been used to produce high value compounds $[45,46]$ and applied to the design of biotechnological processes [47]. Here we investigated the cellulolytic and oxidative system of $P$. cinnabarinus grown in cellulolytic conditions.

In the P. cinnabarinus secretome, we found hemicellulase activities already reported in the literature: $\alpha$ galactosidase, xylanase or $\beta$-galactosidase $[48,49,41]$, together with mannosidase and arabinofuranosidase activities not hitherto described in P. cinnabarinus. Endoglucanase and exoglucanase were identified by zymogram (CMCase) and by hydrolysis of Avicel and CMC. Peroxidase activity assay (manganese peroxidase and lignin peroxidase) was performed on the secretome, but no activity was recovered. $P$. cinnabarinus is a well-known producer of laccase [50], but in cellulolytic conditions, laccase production seems to be repressed, whereas the zymogram shows activity on ABTS around $50 \mathrm{kDa}$. Similar results were observed in $P$. chrysosporium grown in cellulolytic condition with the presence of several laccase bands on the zymogram around $50 \mathrm{kDa}$ confirmed by electron paramagnetic resonance [51]. Production of $\mathrm{CDH}$ was previously described $[41,25]$ and its activity was followed in $P$. cinnabarinus culture.

We cloned and expressed $P$. cinnabarinus $\mathrm{CDH}$ in $P$. pastoris. $\mathrm{CDH}$ of T. versicolor [52], $P$. chrysosporium [53] and more recently $N$. crassa [13] were previously expressed in the same host. These results confirm that $P$. pastoris heterologous expression is an efficient way to produce fungal $\mathrm{CDHs}$ at high levels. 
A

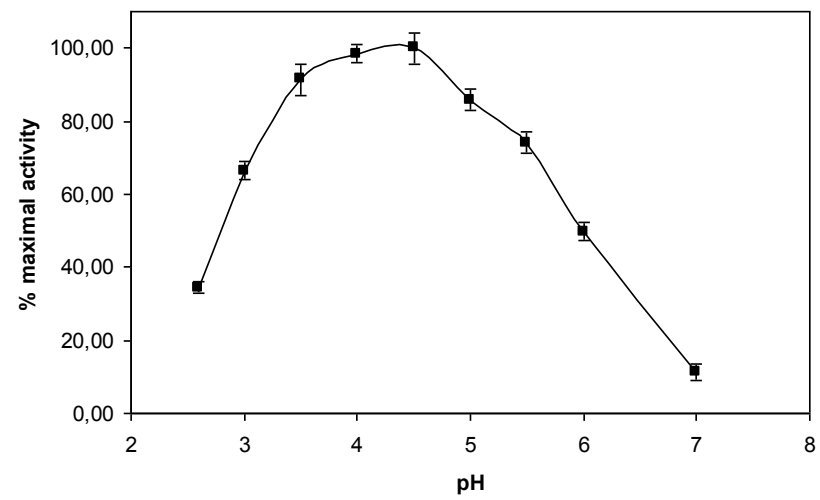

B

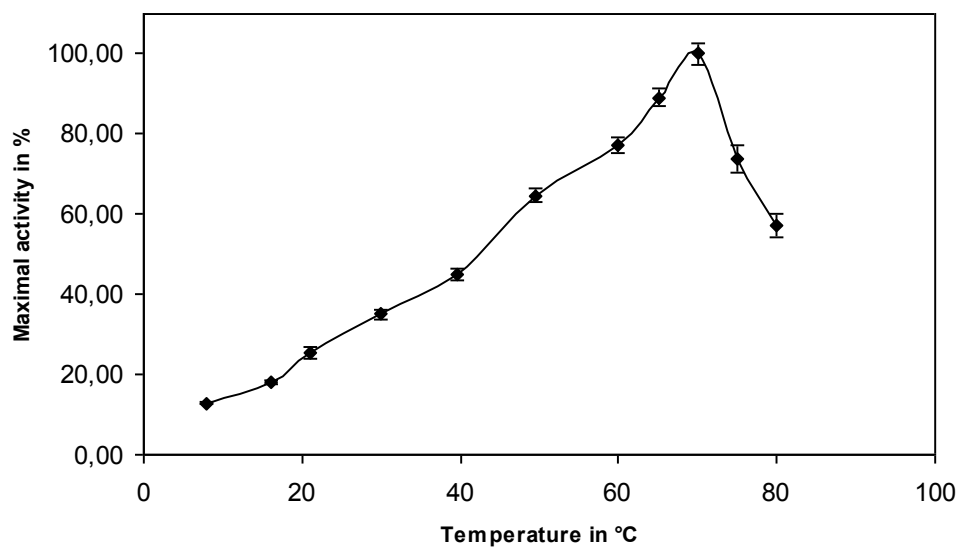

$\mathrm{C}$

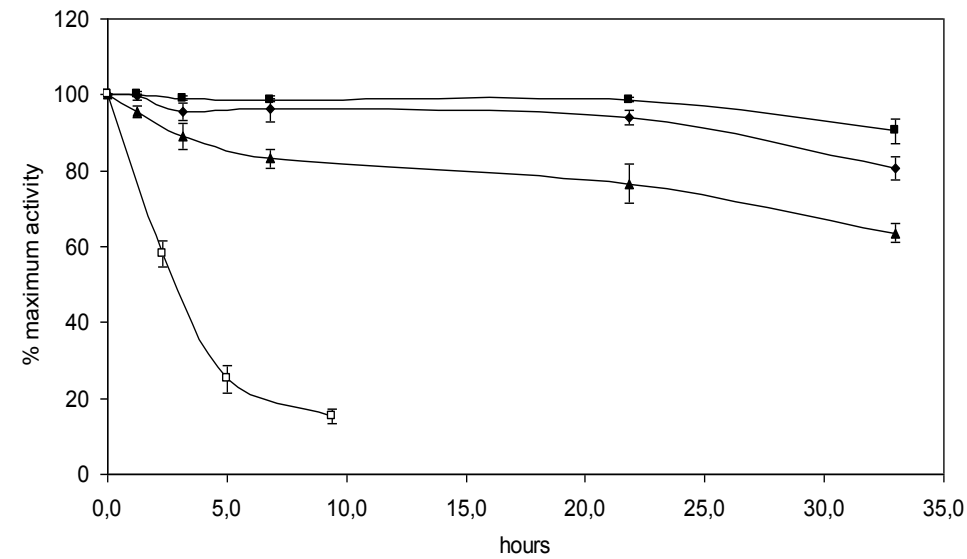

Figure 4 Effect of temperature on the activity of purified rCDH using DCPIP as electron acceptor. Activity was determined at $\mathrm{pH} 4.5$ except for determination of optimal $\mathrm{pH}$. (A) Optimal $\mathrm{pH}$ of purified $\mathrm{rCDH}$ using DCPIP as electron acceptor. Activity was determined at $30^{\circ} \mathrm{C}$ in citrate-phosphate buffer pH 2.7-7. (B) Temperature optimum. (C) Temperature stability at $45^{\circ} \mathrm{C}(\boldsymbol{\bullet}), 50^{\circ} \mathrm{C}(\bullet), 55^{\circ} \mathrm{C}(\boldsymbol{\bullet})$ and $65^{\circ} \mathrm{C}(\square)$. Measured were performed at least three times. 
Table 2 Apparent kinetic constants of purified rCDH for cellobiose

\begin{tabular}{|c|c|c|c|c|}
\hline Electron acceptor & $K \mathrm{M}(\mu \mathrm{M})$ & $V \max { }^{a}(\mu \mathrm{mol} / \mathrm{min} / \mathrm{mg})$ & kcat (s-1) & kcat/KM (s-1. mM-1) \\
\hline DCPIP & 35.5 & 22.2 & 40.8 & 1148 \\
\hline Cyt C & 14.7 & 3.9 & 7.0 & 474 \\
\hline
\end{tabular}

Reactions were performed at $30^{\circ} \mathrm{C}, \mathrm{pH} 4.5$ using selected electron acceptors.

${ }^{a}$ Kinetic parameters were determined using DCPIP or cyt $\mathrm{c}$ as electron acceptor and cellobiose as substrate under standard assay conditions.

Enzymatic characterization of recombinant $\mathrm{CDH}$ gave values of kinetic parameters $\left(V_{\max }, K_{\mathrm{M}}\right)$ in the same range as those observed previously for the native enzyme [25] and more generally for the recombinant $\mathrm{CDH}$ cited in the literature $[12,52]$. However, recombinant $\mathrm{CDH}$ of $P$. cinnabarinus is more thermostable than the other fungal CDHs, with an optimal temperature around $70^{\circ} \mathrm{C}$. Optimal $\mathrm{pH} 4.5$ is in close agreement with the literature.

Some CDHs produced by ascomycetes and soft-rot fungi contain a carbohydrate binding module (CBM) and are able to bind cellulose. In the case of P. chrysosporium $\mathrm{CDH}$, the ability to bind cellulose seems to be mediated by a specific domain with a structure different from CBM [31]. The ability of the purified enzyme to bind Avicel in the absence of CBM was confirmed experimentally.

$\mathrm{CDH}$ is produced simultaneously with cellulase. Its role in the degradation of cellulose was shown by Bao et al., who found that $P$. chrysosporium $\mathrm{CDH}$ increased the sugar yield from cellulose and produced cellobionolactone [39]. In this work, we decided to use $\mathrm{CDH}$ to supplement cellulase cocktail on complex substrate such as wheat straw.

In a first set of experiments, we used the $P$. cinnabarinus secretome containing $\mathrm{CDH}$ added directly to cellulase cocktail for the saccharification of wheat straw.

Results on wheat straw showed (i) increased yield in C5 sugars from hemicelluloses, consistent with the lignin degradation effect of the secretome, and (ii) a slight decrease in glucose yield correlated with the formation of large amounts of gluconic acid due to cleavage of cellobionic acid (the main product of the reaction performed by $\mathrm{CDH}$ ) by $\beta$-glucosidase.

Supplementation with purified $\mathrm{rCDH}$ gave similar results on wheat straw and even no decrease in glucose yield, but gluconic acid and C5 sugar hemicellulose production was enhanced for $10 \mathrm{U} \mathrm{CDH}$ supplementation. Results point to synergy between $\mathrm{CDH}$ and cellulases for degradation of raw material. In $P$. cinnabarinus secretome, $\beta$-glucosidase activity was significantly detected (Table 1). However, when no $\beta$-glucosidase was added to the saccharification assay, more cellobionic acid was produced instead of gluconic acid by $T$. reesei cocktail supplemented with $P$. cinnabarinus secretome (data not shown). It is well established that $\beta$-glucosidases are inhibited by gluconolactone and more generally that lactones are inhibitors of many glycosidases [54,55]. Nevertheless, sugar lactones are unstable in aqueous solution, and the rate of spontaneous hydrolysis to the corresponding aldonic acid, i.e. gluconic acid or cellobionic acid, depends on the $\mathrm{pH}$ and temperature of the reaction. Aldonolactonase, found in several fungi, catalyzes the hydrolysis of lactones to aldonic acid [56]. This hydrolysis should relieve inhibition of $\beta$-glucosidase and glycosidase by lactone, as suggested by Bruchman et al. [57]. $\beta$-Glucosidase is able to cleave cellobionic acid into glucose and gluconic acid [58]; cellobionic acid and gluconic acid production decreases the number of reducing ends as shown by the decrease in DNS titration. In the presence of $\mathrm{CDH}$, DNS titration is not a relevant method for monitoring cellulose degradation. The presence of cellobionic acid seems due to a faster reaction rate of $\mathrm{CDH}$ than $\beta$ glucosidase versus cellobiose, as shown by Yoshida et al. [59]. Supplementation with $\beta$-glucosidase compensates for the difference in reaction rate, leading to a greater production of gluconic acid. Conversely, as the accumulation of cellobiose induces inhibitory effects on cellulase [60], CDH may decrease the cellobiose concentration in the medium faster and so avert inhibition.

\section{Conclusions}

Supplementation of $T$. reesei secretome by CDH increases the overall degradation of lignocellulose and produces appreciable amounts of gluconic acid. In saccharification processes, the use of gluconic acid should offer a way to improve the profitability of the whole process. Several organisms use gluconic acid through the pentose phosphate pathway. Zymomonas mobilis, for example, is able to produce ethanol from gluconic acid by the Entner-Doudoroff pathway [61]. Alcoholic fermentation from gluconic acid by Saccharomyces bulderi has also been reported [62]. The introduction of such organisms able to use pentose and gluconic acid should increase the overall yield of ethanol by using less fermentable components and should offer a way to design a sustainable process for second generation bioethanol production.

\section{Methods}

Biological material

P. cinnabarinus ss3 monokaryotic strain BRFM 137 isolated from the fruit-like structure of the $P$. cinnabarinus 


\section{A}

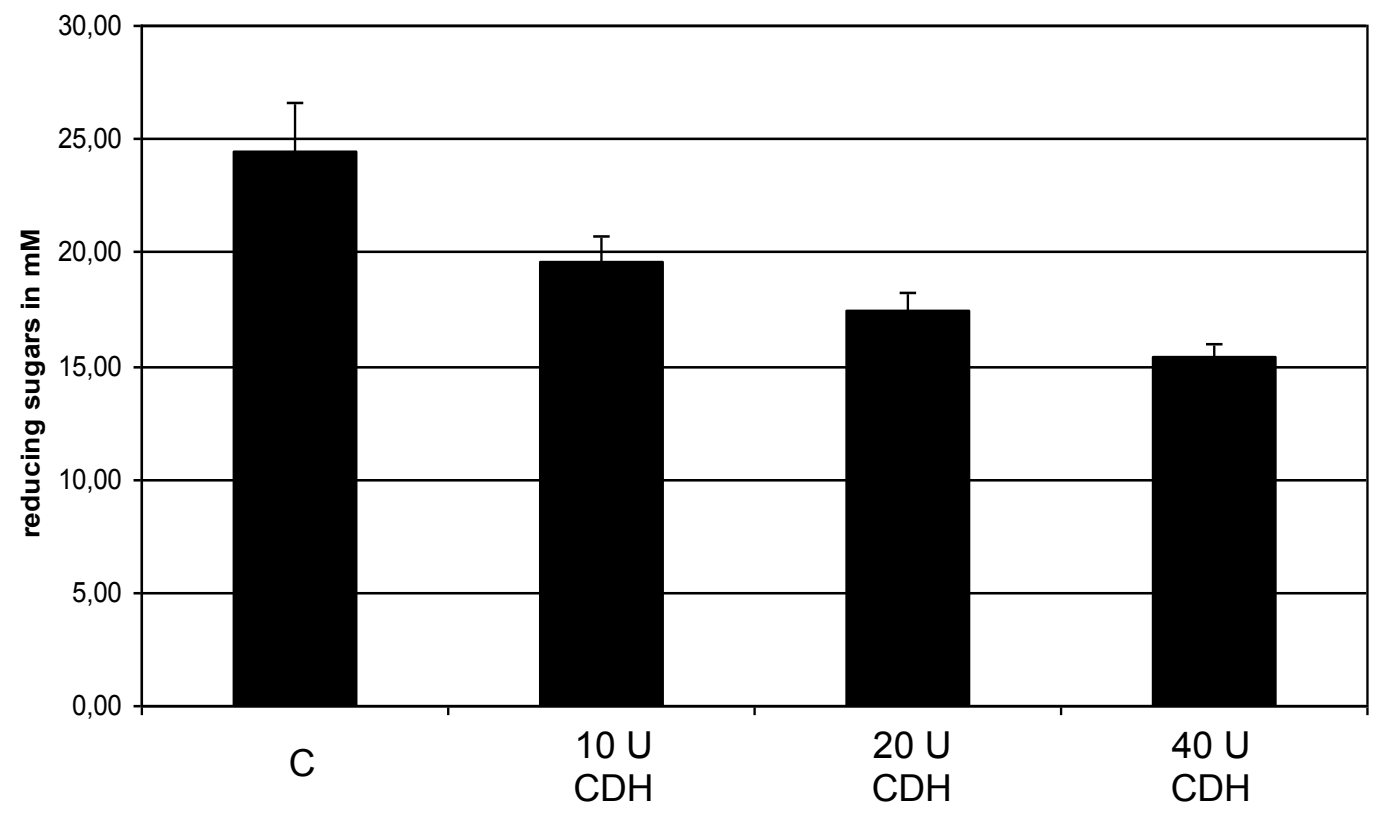

B

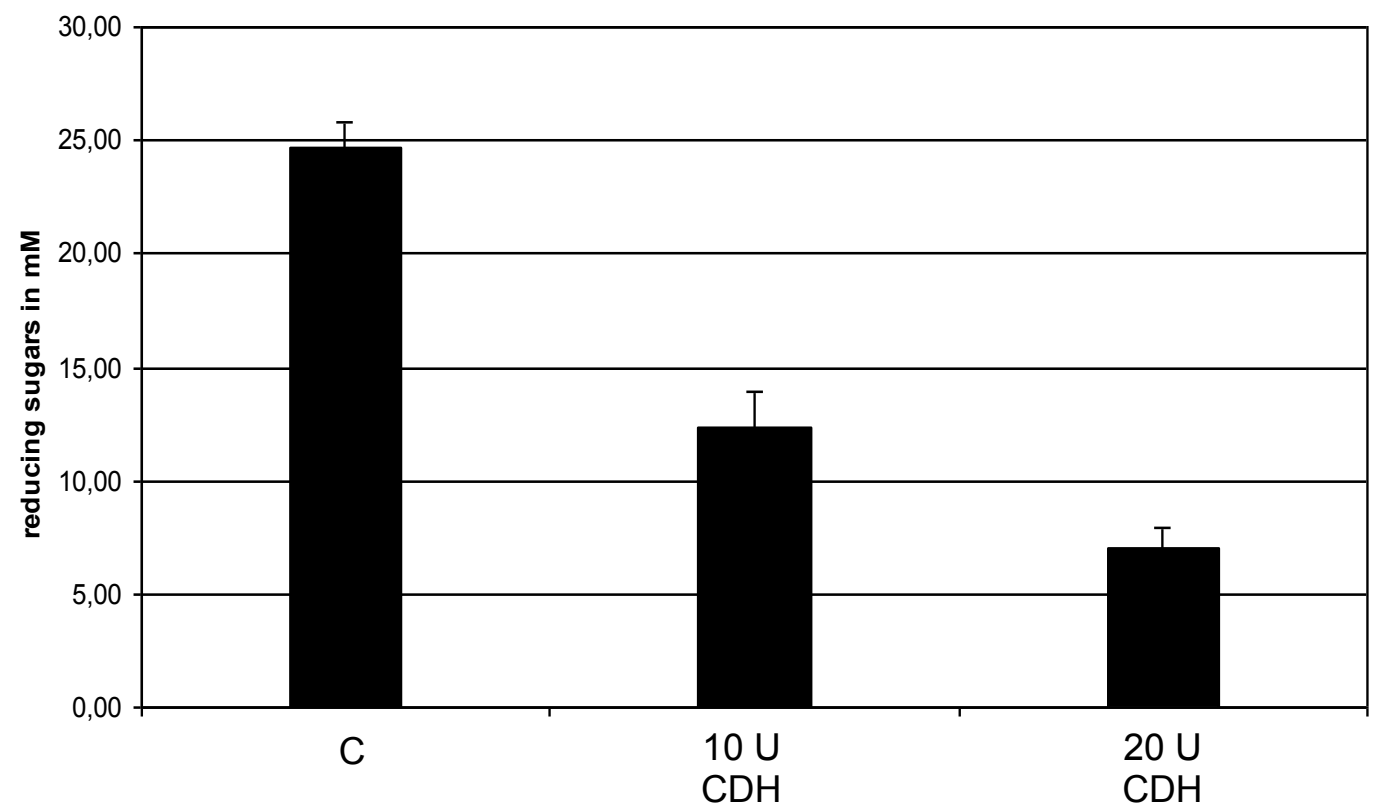

Figure 5 Analysis of total reducing sugar yield after $96 \mathrm{~h}$ of enzymatic treatment on wheat straw. Reducing sugars (mM) release during hydrolysis were quantified spectrophotometrically using the DNS method as described in Navarro et al., 2010 [69]. Assay conditions for hydrolysis were conducted in $20 \mathrm{~mL}$ of $50 \mathrm{mM}$ sodium phosphate buffer $(\mathrm{pH} 4.8)$ containing $5 \%(\mathrm{w} / \mathrm{v})$ wheat straw. (A) P. cinnabarinus secretome containing $\mathrm{CDH}$ or (B) purified $\mathrm{rCDH}$ were assayed in the presence of cellulose cocktail at $45^{\circ} \mathrm{C}$ with an orbital agitation (140 rpm) during 96 h. C: control reaction without CDH. Error bars are for triplicate, each measured once. 
A

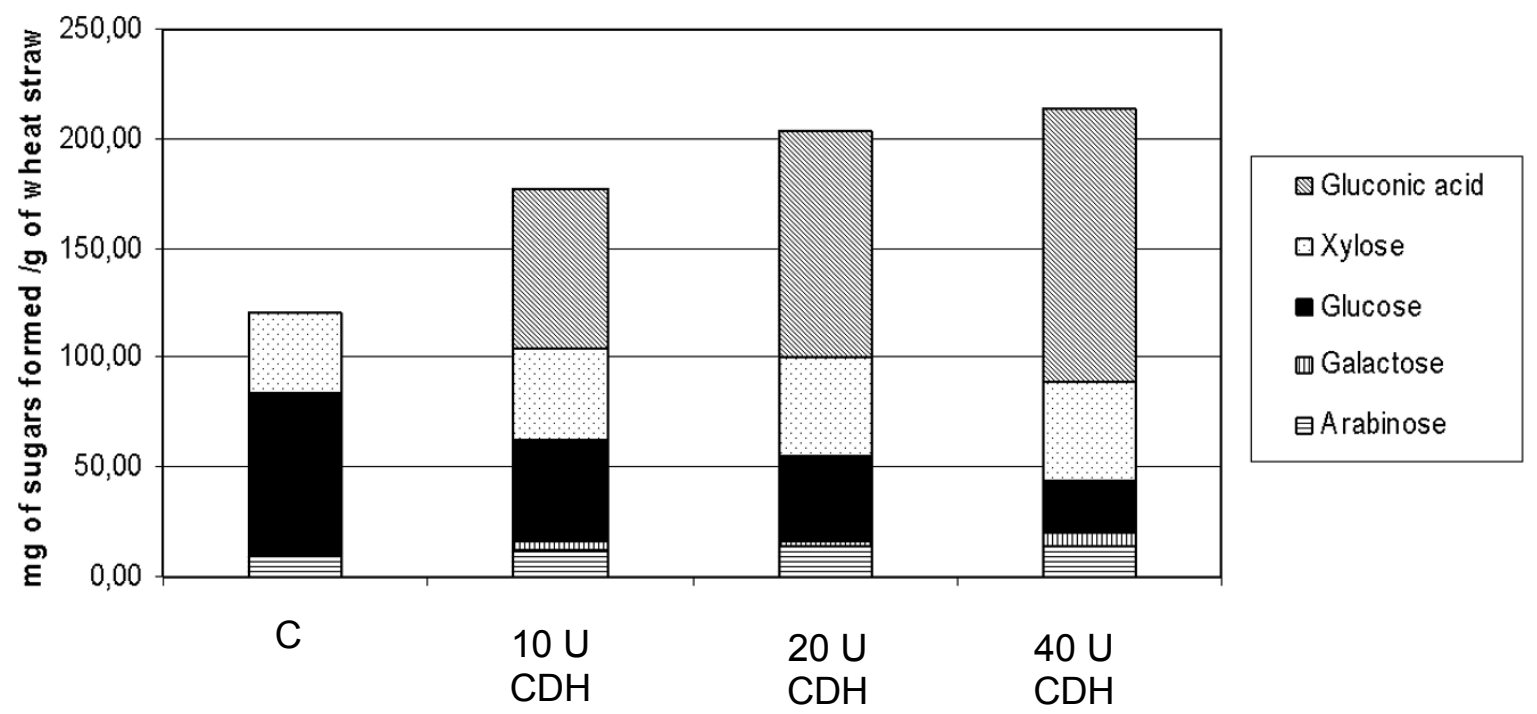

B

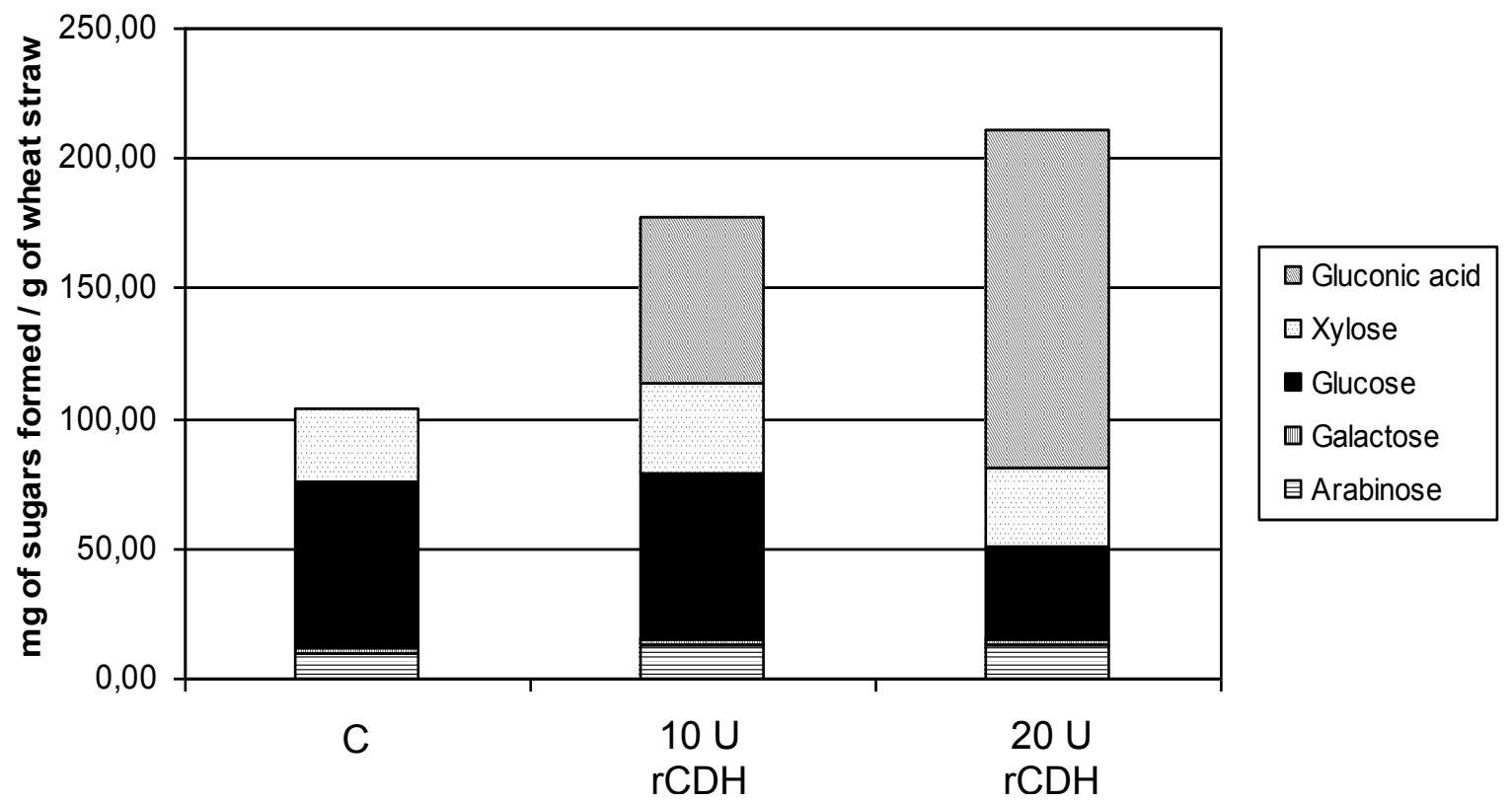

Figure 6 Determination of sugar yield in $\mathrm{mg}$ of sugars formed/g of wheat straw after $96 \mathrm{~h}$ of enzymatic treatment on wheat straw Saccharification assays were performed in $20 \mathrm{~mL}$ of $50 \mathrm{mM}$ sodium phosphate buffer ( $\mathrm{pH}$ 4.8) containing $5 \%(\mathrm{w} / \mathrm{v})$ wheat straw. (A) P.

cinnabarinus secretome containing $\mathrm{CDH}$ or (B) purified $\mathrm{rCDH}$ were assayed in the presence of cellulose cocktail at $45^{\circ} \mathrm{C}$ with an orbital agitation (140 rpm) during 96 h. C: control reaction without CDH. Sugars were quantified by high-performance anion exchange chromatography (HPAEC) coupled with amperometric detection (PAD) equipped with a Carbo-Pac PA-1 analytical column. These experiments were repeated at least three times with similar results. For all-sugars analysis in (A) and (B) statistical significance was $P<0.1$ and $P<0.05$ respectively. 
I-937 dikaryotic strain was maintained as previously described [50]. P. pastoris strain X33 is a component of the Pichia Easy Select Expression System and the pPICZ $\alpha$ A vector (Invitrogen, Cergy-Pontoise, France).

\section{Media and culture conditions}

P. cinnabarinus was grown at $30^{\circ} \mathrm{C}$ on MYA2 plates (maltose: $20 \mathrm{~g} / \mathrm{L}$; yeast extract: $1 \mathrm{~g} / \mathrm{L}$; agar $16 \mathrm{~g} / \mathrm{L}$ ). After 10 days of incubation, precultures in Roux flasks containing $200 \mathrm{~mL}$ of medium were inoculated with five disks of $P$. cinnabarinus grown in $\mathrm{MYA}_{2}$ plates. Inoculum was obtained from 10-day-old static precultures incubated at $30^{\circ} \mathrm{C}$.

We used $10 \mathrm{~mL}$ of inoculum suspension obtained from Ultra-Turrax-mixed mycelial mats to inoculate 500 $\mathrm{mL}$ baffled conical flasks containing $250 \mathrm{~mL}$ of basal medium composed of cellulose fibrous medium (Sigma, St. Louis, Mo, USA) (15 g/L), diammonium tartrate $(1.84 \mathrm{~g} / \mathrm{L})$, disodium tartrate $(2.3 \mathrm{~g} / \mathrm{L}), \mathrm{KH}_{2} \mathrm{PO}_{4}(1.33 \mathrm{~g} /$ $\mathrm{L}), \mathrm{CaCl}_{2} \cdot \mathrm{H}_{2} \mathrm{O}(0.1 \mathrm{~g} / \mathrm{L}), \mathrm{MgSO}_{4} .7 \mathrm{H}_{2} \mathrm{O}(0.5 \mathrm{~g} / \mathrm{L})$, FeS$\mathrm{O}_{4} .7 \mathrm{H}_{2} \mathrm{O}(0.07 \mathrm{~g} / \mathrm{L}), \mathrm{ZnSO}_{4} .7 \mathrm{H}_{2} \mathrm{O}(0.046 \mathrm{~g} / \mathrm{L}), \mathrm{MnSO}_{4}$. $\mathrm{H}_{2} \mathrm{O}(0.035 \mathrm{~g} / \mathrm{L}), \mathrm{CuSO}_{4} .5 \mathrm{H}_{2} \mathrm{O}(0.007 \mathrm{~g} / \mathrm{L})$, yeast extract $(1 \mathrm{~g} / \mathrm{L})$, vitamin solution $(1 \mathrm{~mL} / \mathrm{L})$ according to Tatum et al. [63] maltose $(2.5 \mathrm{~g} / \mathrm{L})$ used as starter and Tween $80(1.5 \mathrm{~g} / \mathrm{L})$, according to [41]. For the heterologous expression of $\mathrm{CDH}$ in Pichia pastoris, all media and protocols are described in the Pichia expression manual (Invitrogen). Cloning procedures were performed using one-shot TOP 10 and DH5 $\alpha$ chemically competent Escherichia coli cells (Invitrogen).

\section{Isolation of mRNA and cloning of $c d h$ CDNA gene}

Isolation of total RNA was performed on a 4-day-old culture of $P$. cinnabarinus on cellulose medium using Total RNA Purification from Plant (Macherey-Nagel, Düren, Germany) as prescribed by the manufacturer. Contaminant DNA was digested by Turbo DNase (Ambion Inc., Austin, TX, USA) according to the manufacturer's instructions. First-strand cDNA synthesis was performed using SuperScript reverse transcriptase (Invitrogen) and oligo $\left(\mathrm{dT}_{18}\right)$ primer following the manufacturer's instructions. The amplification of the full-length $c d h$ cDNA was performed using specific primers (with restriction sites underlined): forward primer $\mathrm{cdhF}\left(5^{\prime} \mathrm{TA}\right.$ GAA TTC CAA GTG GCA GCG CCA TAC 3') and reverse primer cdhR ( 5 ' TA TCT AGA CCA GGA CCT CCC GCA AGG GC 3') designed from $P$. cinnabarinus I-937 $c d h$ gene (NCBI AF081574): 315 ng of cDNA was mixed with 300 pmol of each primer cdhF and cdhR, $200 \mu \mathrm{M}$ dNTPs, and 0.5U Pfu DNA polymerase (Promega, Madison, WI, USA). The reaction was performed with the following amplification program: 1 cycle at $95^{\circ}$ $\mathrm{C}$ for $5 \mathrm{~min}, 30$ cycles composed of three steps for each cycle $\left(95^{\circ} \mathrm{C}\right.$ for $1 \mathrm{~min}, 65^{\circ} \mathrm{C}$ for $30 \mathrm{~s}$ and $72^{\circ} \mathrm{C}$ for 4 min), and a final step at $72^{\circ} \mathrm{C}$ for $10 \mathrm{~min}$. PCR amplicons generated by $P f u$ DNA polymerase are bluntended. To add an A-tail on these PCR fragments before subcloning into pGEMT-easy vector, Taq DNA polymerase (Promega) was used as described in the pGEMT-easy vector Technical Manual (Promega). The $2.3 \mathrm{~kb}$ PCR product was purified using the Qiaquick gel extraction kit (Qiagen, Valencia, CA, USA) and subcloned into pGEMT easy vector.

The $c d h$ cDNA was further sequenced (GATC Biotech, Mulhouse, France) using sp6 and T7 universal primers and cdhint (5' CGA CGC CCA GAA CTC GAA C 3'). The P. cinnabarinus sequence was deposited in the NCBI databank (GenBank accession number: BankIt1421219 Pycnoporus HQ825322). Comparisons of P. cinnabarinus I-937 $c d h$ (GenBank accession number: AF081574.1), T. versicolor cdh (GenBank accession number: AY187939.1) and P. chrysosporium cdh (GenBank accession number: U46081.1) were performed with ClustalW2 software http://www.ebi.ac.uk/Tools/msa/ clustalw2/.

\section{Construction of $\mathrm{pPiCZ} \alpha \mathrm{A}$ expression vector}

The $c d h$ cDNA cloned into pGEMT easy vector was digested using EcoRI and $X b a I$ and purified with a Qiaquick gel extraction kit. In parallel, pPICZ $\alpha$ A was linearized using the same restriction enzymes, and $c d h$ cDNA was ligated at the corresponding sites into pPIC$\mathrm{Z} \alpha \mathrm{A}$ in frame with both the yeast $\alpha$-secretion factor and $\mathrm{C}$-term-(His) ${ }_{6}$-tag encoding sequences. Expression vector pPICZaA-cdh was purified by Qiagen Midiprep and sequenced using 3'AOX and 5'AOX primers to confirm the correct sequence insertion.

\section{Transformation and screening}

Transformation of competent $P$. pastoris X33 was performed by electroporation with PmeI linearized pPICZ $\alpha$ A-cdh as described in Couturier et al. 2010 [64]. The vector pPICZ $\alpha$ without insert was used as a control. Transformants were first screened on YPDS plates with different concentrations of zeocin (100 to $1000 \mu \mathrm{g} / \mathrm{mL}$ ). After incubation at $30^{\circ} \mathrm{C}$, transformants were picked from minimal dextrose (MD) plates and transferred to minimal methanol plates (MM). Zeocin-resistant $P$. pastoris transformants were then screened for protein expression in 10 $\mathrm{mL}$ of BMGY (in $50 \mathrm{~mL}$ tubes) at $30^{\circ} \mathrm{C}$ in an orbital shaker (200 rpm) for $16 \mathrm{~h}$ to an $\mathrm{OD}_{600}$ of 2-6, and expression was induced by transferring cells into $2 \mathrm{~mL}$ of BMMY and growing for a further 3 days. Each day the medium was supplemented with $3 \%(\mathrm{v} / \mathrm{v})$ methanol. The supernatant was then analyzed by SDS-PAGE to determine which transformant had the best secretion yield. 


\section{Recombinant $\mathrm{CDH}$ production}

The best-producing transformant was grown in 1 liter of BMGY in shaken flasks as described above. The cells were then transferred to $200 \mathrm{~mL}$ of BMMY and stirred at $200 \mathrm{rpm}$ at $30^{\circ} \mathrm{C}$ for 4 days.

Bioreactor production of the best-producing transformant was carried out in a 1-liter bioreactor Tryton (Pierre Guerin, Mauze, France) according to the Pichia Fermentation Process Guidelines (Invitrogen) except for the volume of methanol added in the methanol fed batch, which was changed from $3.6 \mathrm{~mL} / \mathrm{h} / \mathrm{L}$ to $3 \mathrm{~mL} / \mathrm{h} /$ L.

\section{Enzyme purification}

Culture supernatant was concentrated at least 10 times using Amicon centrifugal units with a $30 \mathrm{kDa}$ cut-off, $4000 \times g$ or Amicon vivaflow (Millipore, Bedford, MA, USA) with a $30 \mathrm{kDa}$ cut-off, depending on culture volume. The concentrated supernatant was dialyzed against buffer A (Tris- $\mathrm{HCl} 50 \mathrm{mM} 7.8, \mathrm{NaCl} 150 \mathrm{mM}$ and imidazole $10 \mathrm{mM}$ ), and loaded on a nickel chelate His-Bind Resin (GE Healthcare, Buc, France) column $(0.7 \times 5 \mathrm{~cm})$ connected to an Äkta FPLC (GE Healthcare) and equilibrated with buffer A. The His-tagged $\mathrm{rCDH}$ was eluted with buffer B (Tris- $\mathrm{HCl} 50 \mathrm{mM} \mathrm{pH}$ 7.7, imidazole $500 \mathrm{mM}$ and $\mathrm{NaCl} 150 \mathrm{mM}$ ). Active fractions were pooled, concentrated and dialyzed against sodium acetate buffer (50 mM, pH 5)

\section{SDS-PAGE, Western blot and zymogram}

Polyacrylamide gel electrophoresis (SDS-PAGE) (12\%) was prepared as described by Laemmli [65]. Protein bands were stained with Coomassie blue G 250. The molecular mass under denaturating conditions was determined with reference standard proteins (LMW, Amersham Pharmacia Biotech, Orsay, France or unstained protein molecular weight marker, Euromedex, Souffelweyersheim, France).

Enzyme activities were assayed in polyacrylamide gels containing the appropriate substrates. Enzyme preparations were run on an SDS-PAGE gel copolymerized with $0.2 \%$ soluble xylan, $0.2 \%$ carboxymethylcellulose (CMC) or $0.2 \%$ locust bean gum for the analysis of xylanase, CMCase or mannanase activities, respectively. The protein samples were mixed in the loading buffer (3\% SDS w/v, 10\% glycerol w/v and $30 \mathrm{mM}$ Tris- $\mathrm{HCl}$ buffer $\mathrm{pH}$ 6.8) without reducing agent, heated at $100^{\circ} \mathrm{C}$ for 1 min and then separated using a $12 \%$ polyacrylamide gel. After electrophoresis, the gel was washed with deionized water and soaked in $2.5 \%(\mathrm{v} / \mathrm{v})$ Triton X-100. After $1 \mathrm{~h}$ incubation at $4^{\circ} \mathrm{C}$, the gel was soaked in 100 $\mathrm{mM}$ sodium phosphate buffer ( $\mathrm{pH} \mathrm{5}$ ) at $45^{\circ} \mathrm{C}$ for $2 \mathrm{~h}$ for the detection of xylanase and CMCase activity or in 100 $\mathrm{mM}$ sodium phosphate buffer $(\mathrm{pH} 7)$ for $1 \mathrm{~h}$ at $50^{\circ} \mathrm{C}$ for the detection of mannanase activity. After incubation the gel was stained with $0.1 \%$ Congo red solution under gentle shaking for $1 \mathrm{~h}$ and destained with $1 \mathrm{M} \mathrm{NaCl}$ for $1 \mathrm{~h}$. Protein bands exhibiting xylanase, CMCase and mannanase activity were seen as clear bands on the red background.

For laccase and $\mathrm{CDH}$ zymograms, samples were mixed with the same loading buffer as described above without heating; they were incubated at ambient temperature for $15 \mathrm{~min}$ and the gel was run. After electrophoresis the gel was soaked in $2.5 \%$ Triton X100 for $1 \mathrm{~h}$ at $4^{\circ} \mathrm{C}$, rinsed with deionized water and incubated for $2 \mathrm{~h}$ at $25^{\circ} \mathrm{C}$ in $50 \mathrm{mM}$ sodium acetate buffer ( $\mathrm{pH} 5$ ) with $4 \mathrm{mM}$ sodium fluoride for $\mathrm{CDH}$ and $50 \mathrm{mM}$ sodium tartrate buffer $(\mathrm{pH} \mathrm{4})$ for laccase. Visualization was performed by adding $5 \mathrm{mM}$ ABTS to stain for laccase and adding $50 \mathrm{mM}$ DCPIP for $\mathrm{CDH}$, staining the gel dark blue. $\mathrm{CDH}$ activity was then visualized by adding $100 \mathrm{mM}$ cellobiose. Protein bands exhibiting CDH activity were seen as clear bands on the dark blue background. Western blot analysis was performed as described previously, using the monoclonal anti-polyhistidine alkaline phosphatase conjugate (Sigma) for Western blot analysis of $\mathrm{rCDH}$ expressed in P. pastoris. For Western blot analysis, purified $\mathrm{rCDH}$ was run on a $12 \%$ SDS/polyacrylamide gel and blotted onto a PVDF membrane using the iBlot Dry Blotting System (Invitrogen). Membranes were placed in a Snap Protein Detection System (Millipore, Bedford, MA, USA) used for immunodetection. Following the manufacturer's instructions, the PVDF membrane was incubated in TBS blocking solution $(10 \mathrm{mM}$ Tris, $150 \mathrm{mM} \mathrm{NaCl}$ and $0.1 \%$ Tween 20 , $\mathrm{pH} 8$ ) with addition of $0.1 \%(\mathrm{w} / \mathrm{v})$ of skimmed milk powder and then washed with TBS. Immunodetection was performed using the monoclonal anti-polyhistidine alkaline phosphatase conjugate (Sigma,). Signal detection was carried out using $60 \mu \mathrm{L}$ of BCIP (5bromo-4-chloro-3-indolyl-phosphate), $60 \mu \mathrm{L}$ of NBT (4-nitro blue tetrazolium) (Roche Applied Science, Meylan, France) in $20 \mathrm{~mL}$ carbonate buffer $0.05 \mathrm{M} \mathrm{pH}$ 9.6 with addition of $5 \mathrm{mM} \mathrm{MgCl} 2$.

Papain cleavage of the two $\mathrm{CDH}$ domains was carried out as described by Henriksson et al. [43]. Deglycosylation was performed using PGNase (New England Biolabs, Saint-Quentin-en-Yvelines, France) to remove rCDH N-linked glycans according to the manufacturer's instructions.

\section{Protein assay}

Protein concentration was determined using the Bio-Rad Protein Assay (Bio-Rad, Marnes-la-Coquette, France), based on the Bradford procedure, using bovine serum albumin as standard [66]. 


\section{Binding studies}

Assays were performed with $1 \mathrm{mg} / \mathrm{mL}$ of Avicel PH-101 (Sigma) in $50 \mathrm{mM}$ citrate phosphate buffer $\mathrm{pH} 5$ under orbital agitation at room temperature, and $\mathrm{rCDH}$ was added in the range $0.02-0.8 \mu \mathrm{g} / \mathrm{L}$. After $3 \mathrm{~h}$, Avicel PH101 was removed by centrifuging, and the concentration of free enzyme $([\mathrm{FE}], \mu \mathrm{M})$ in the supernatant was measured by activity assay. The bound enzyme concentration ([BE] in $\mu$ mol per gram of Avicel $\mathrm{PH}-101)$ was determined by subtracting [FE] from the total protein concentration. All the assays were carried out in triplicate. Adsorption parameters were based on typical double-reciprocal plots using the equation $[\mathrm{B}]=[\mathrm{UB}] \times[\mathrm{B}]$ $\max /\left(K_{\mathrm{d}}+[\mathrm{UB}]\right)$, where $K_{\mathrm{d}}(\mu \mathrm{M})$ and $[\mathrm{B}]_{\max }(\mu$ mol per gram of Avicel $\mathrm{PH}-101)$ are the equilibrium dissociation constant and the maximum amount of protein bound. Two controls were run, one without $\mathrm{rCDH}$ and the other with BSA at $1 \mu \mathrm{g} / \mu \mathrm{L}$ to estimate unspecific fixation of $\mathrm{rCDH}$. Measures were repeated at least three times.

\section{Enzyme assays}

To measure enzyme activities in the $P$. cinnabarinus culture supernatant, each aliquot was centrifuged for 5 $\mathrm{min}$ at $3500 \mathrm{rpm}$ and filtered through a $0.45 \mu \mathrm{m}$ membrane (Millipore, Bedford, MA, USA). CDH activities were determined by monitoring the reduction of 0.2 $\mathrm{mM}$ 2,6-dichlorophenol indophenol (DCPIP) in 100 $\mathrm{mM}$ sodium acetate buffer ( $\mathrm{pH} 5)$ containing $2 \mathrm{mM}$ cellobiose and $4 \mathrm{mM}$ of sodium fluoride (sodium fluoride was used as a laccase inhibitor). The decrease in absorption at $520 \mathrm{~nm}\left(\varepsilon=6800 \mathrm{M}^{-1} \cdot \mathrm{cm}^{-1}\right)$ was monitored at $30^{\circ} \mathrm{C}$ for $1 \mathrm{~min}$. Alternatively, $\mathrm{CDH}$ activity was determined by monitoring the reduction of $50 \mu \mathrm{M}$ cytochrome c (cyt c) in $100 \mathrm{mM}$ sodium-acetate buffer (pH 5) containing $2 \mathrm{mM}$ cellobiose. The decrease in absorption at $550 \mathrm{~nm}\left(\varepsilon=33,700 \mathrm{M}^{-1} \cdot \mathrm{cm}^{-1}\right)$ was monitored at $30^{\circ} \mathrm{C}$ for $1 \mathrm{~min}$. Glucose oxidase was measured using the D-gluconic acid / D-glucono- $\delta$-lactone assay (Megazyme). Laccase activity was determined quantitatively by monitoring the oxidation of $5 \mathrm{mM}$ ABTS (2, 2'-azinobis (3-ethylbenzthiazoline-6-sulfonic acid)) at $420 \mathrm{~nm}$ (extinction coefficient $36,000 \mathrm{mM}^{-1} \mathrm{~cm}^{-1}$ ) in the presence of $50 \mathrm{mM} \mathrm{NaK}$ tartrate, $\mathrm{pH}$ 4.0. Lignin peroxidase activity was determined spectrophotometrically at $30^{\circ} \mathrm{C}$ by the method of Tien and Kirk [67]. Manganese peroxidase activity was determined spectrophotometrically at $30^{\circ} \mathrm{C}$ by the method of Paszczynski et al. [68] using $\mathrm{H}_{2} \mathrm{O}_{2}$ and vanillylacetone as substrate. Enzyme activity was expressed in international units (IU). One unit of activity is defined as the quantity of enzyme that transforms $1 \mu \mathrm{mol}$ of substrate in one minute.

Hydrolysis assays for glycosidases were carried out in $50 \mathrm{mM}$ acetate buffer $\mathrm{pH} 5$ containing $1 \mathrm{mM}$ of substrate in a final volume of $100 \mu \mathrm{L}$. Substrates pNP- $\beta$ $\mathrm{D}$-glucopyranoside, $\mathrm{pNP}-\beta$-D-cellobiopyranoside, $\mathrm{pNP}$ $\beta$-D-xylopyranoside, $\alpha$-D-galactopyranoside and pNP- $\beta$ D-mannopyranoside were purchased from Sigma. Assays were performed with 0.5 and $1 \mu \mathrm{g}$ of protein, and incubated for $37^{\circ} \mathrm{C}$ for $1 \mathrm{~h}$ with shaking (300 rpm). To stop the reaction, $130 \mu \mathrm{L}$ of $\mathrm{Na}_{2} \mathrm{CO}_{3} 1 \mathrm{M}$ was added, and absorbance was read at $410 \mathrm{~nm}$. A control was run with $100 \mu \mathrm{L}$ of $50 \mathrm{mM}$ acetate buffer $\mathrm{pH} 5$ and references ranging from 0.02 to $0.2 \mathrm{mM}$ of 4-nitrophenyl were measured in parallel. Enzymatic activity was based on colorimetric assay of free pNP present in the reaction after hydrolysis. This activity is expressed in $\mathrm{U} / \mathrm{mg}$ of proteins.

Hydrolysis assays were carried out in $50 \mathrm{mM}$ acetate buffer $\mathrm{pH} 5$ containing $1 \%(\mathrm{w} / \mathrm{v})$ of substrates. Carboxymethyl cellulose (CMC, low viscosity) and citrus pectin were purchased from Sigma. Wheat arabinoxylan (low viscosity) and galactomannan (low viscosity) were from Megazyme. Assays were performed with 10 and $30 \mu \mathrm{g}$ of protein, and incubated at $37^{\circ} \mathrm{C}$ for $1 \mathrm{~h}$ with shaking (150 rpm). Reducing sugars released during hydrolysis were quantified by DNS (3, 5-dinitrosalycylic acid) visualization at $540 \mathrm{~nm}$ as described in Navarro et al., 2010 [69]. Controls were run with $50 \mathrm{mM}$ acetate buffer $\mathrm{pH} 5$ and references ranging from 1 to $10 \mathrm{mM}$ of glucose were measured in parallel for each series. Enzymatic activity is expressed in $\mathrm{U} / \mathrm{mg}$ of proteins. Three controls were performed with the secretome alone to quantify sugars present in culture supernatant. Controls were subtracted from measured values. All assays were performed in triplicate.

\section{Effect of $\mathrm{pH}$ and temperature on the activity and stability of $\mathrm{rCDH}$}

To determine the optimum $\mathrm{pH}$ of the $\mathrm{rCDH}$, the activity was measured with DCPIP using $50 \mathrm{mM}$ citrate phosphate buffer in the $\mathrm{pH}$ range $2.5-7$ at $30^{\circ} \mathrm{C}$. For optimum temperature determination, activity on DCPIP was measured using $50 \mathrm{mM}$ citrate phosphate buffer in the temperature range $10-80^{\circ} \mathrm{C}$. Thermal stability of $\mathrm{rCDH}$ was determined by incubating enzymes for $33 \mathrm{~h}$ at 45,50 and $55^{\circ} \mathrm{C}$ and for $10 \mathrm{~h}$ at $65^{\circ} \mathrm{C}$. Native CDH activity assay was performed in triplicate as described above.

\section{Enzyme kinetics}

The kinetic parameters $\left(V_{\max }\right.$ and $\left.K_{\mathrm{m}}\right)$ were determined for cellobiose oxidation measured at $30^{\circ} \mathrm{C}$ in $50 \mathrm{mM}$ citrate phosphate buffer $\mathrm{pH} 4.5$ using DCPIP or cytochrome c. The concentration of cellobiose ranged from 10 to $700 \mu \mathrm{M}$ with both electron acceptors (DCPIP and cytochrome c). Triplicates were run to ensure reliable kinetic parameter determination. 
Graphpad prism v.4 (Graphpad Software) was used for the nonlinear regression calculation and kinetic parameter determination.

\section{Saccharification assays}

Saccharification assays were performed in $50 \mathrm{~mL}$ Falcon tubes (BD Bioscience) containing 5\% (w/v) wheat straw in $50 \mathrm{mM}$ sodium phosphate buffer $(\mathrm{pH} 4.8)$ with addition of tetracycline $(12.6 \mathrm{mg} / \mathrm{mL})$ and cycloheximide $(10$ $\mathrm{mg} / \mathrm{mL}$ ). The final reaction volume was $20 \mathrm{~mL}$. Enzymes were added to the basal medium: industrial cocktail GC220 (Genencor-Danisco, Rochester, NY, USA) from T. reesei and Novozyme 188 (Novozyme, Franklinton, NC, USA) from Aspergillus niger, P. cinnabarinus supernatants containing $\mathrm{CDH}$ activity and purified $\mathrm{rCDH}$ expressed by $P$. pastoris. $T$. reesei GC220 enzyme cocktail contained $1.41 \mathrm{U}$ CMCase, $0.79 \mathrm{U} \beta$-glucosidase, $0.11 \mathrm{U}$ cellobiohydrolase, $3.85 \mathrm{U}$ xylanase, $0.26 \mathrm{U}$ mannanase and $0.14 \mathrm{U}$ pectinase per $\mathrm{mg}$ of total protein. $A$. niger Novozyme 188 enzyme cocktail contained 0.06 cellobiohydrolase, $0.18 \mathrm{U}$ CMCase, $1.15 \mathrm{U} \beta$-glucosidase, $0.33 \mathrm{U}$ xylanase, $0.20 \mathrm{U}$ mannanase, $0.14 \mathrm{U} \alpha$-galactosidase and $0.43 \mathrm{U}$ pectinase per $\mathrm{mg}$ of total protein. Activities were measured at $37^{\circ} \mathrm{C}, \mathrm{pH}$ 5.0. Saccharification assays were performed in incubators (Infors AG, Switzerland) at $45^{\circ} \mathrm{C}$ with an orbital shaker $(140 \mathrm{rpm})$ for $96 \mathrm{~h}$. After $96 \mathrm{~h}$ of incubation, all the samples were centrifuged at $3500 \mathrm{rpm}$ for $15 \mathrm{~min}$. The supernatants were filtered through a $0.45 \mu \mathrm{m}$ membrane and carbohydrate was then assayed. Saccharification assays were performed in triplicate.

\section{Carbohydrate determination}

Monosaccharides, cellobiose and gluconic acid generated after hydrolysis of wheat straw were quantified by highperformance anion exchange chromatography (HPAEC) coupled with amperometric detection (PAD) (ICS 3000, Dionex, Sunnyvale, CA, USA) equipped with a CarboPac PA-1 analytical column $(250 \times 4 \mathrm{~mm})$. Enzymatic reactions were stopped by adding $18 \mathrm{mM} \mathrm{NaOH}$ before injection $(5 \mu \mathrm{L})$ into the HPAEC system. Elution $(1 \mathrm{~mL} /$ min) was carried out on a sodium acetate gradient (0$250 \mathrm{mM}$ in $25 \mathrm{~min}$ ). Calibration curves were plotted using galactose, arabinose, glucose, xylose, cellobiose and gluconic acid standards (Sigma-Aldrich), from which response factors were calculated (Chromeleon program, Dionex) and used to estimate the amount of product released in test incubations. All the assays were carried out in triplicate. Reducing sugars released during saccharification assays were quantified by DNS (3, 5dinitrosalycylic acid) method and visualized at $540 \mathrm{~nm}$ as described by Navarro et al. [69]. Controls were run with $50 \mathrm{mM}$ acetate buffer $\mathrm{pH} 5$ and references of glucose were ranging from 1 to $10 \mathrm{mM}$. All assays were performed in triplicate.

\section{List of abbreviations}

$\mathrm{CDH}$ : cellobiose dehydrogenase; CMC: carboxymethylcellulose; DCPIP: 2,6dichlorophenol indophenol; ABTS: 2,2'-azino-bis-(3-ethylbenzthiazoline-6sulfonic acid); pNP: para-nitrophenol; DNS: 3,5-dinitrosalicylic acid; cyt c: cytochrome c; CBM: carbohydrate binding module; rCDH: recombinant cellobiose dehydrogenase.

\section{Acknowledgements}

This work was supported by the Futurol project. We thank Siemeng Zhou for technical assistance in bioreactor culture, CIRM Marseille for supplying Pycnoporus cinnabarinus strain BRFM 137, and Sacha Grisel for sugar analysis.

\section{Author details}

${ }^{1}$ INRA, UMR1163 BCF, 163 avenue de Luminy, 13288 Marseille, France. ${ }^{2}$ AixMarseille Universités, Faculté des Sciences de Luminy, 163 avenue de Luminy, 13288 Marseille, France. ${ }^{3}$ IFP, Institut Français du Pétrole, 1 \& 4 avenue de Bois-Préau 92852 Rueil-Malmaison, France.

\section{Authors' contributions}

$M B$ and $J G B$ designed research. $M B$ and $L P$ carried out experiments. $M B$ and $J G B$ analyzed data. MB, JGB and JCS wrote the paper. All authors read and approved the final manuscript

\section{Competing interests}

The authors declare that they have no competing interests.

Received: 19 October 2011 Accepted: 28 December 2011

Published: 28 December 2011

\section{References}

1. Himmel ME, Ding SY, Johnson DK, Adney WS, Nimlos MR, Brady JW, Foust TD: Biomass recalcitrance: engineering plants and enzymes for biofuels production. Science 2007, 315:804-807.

2. Cherry JR, Fidantsef AL: Directed evolution of industrial enzymes: An update. Curr Opin Biotechnol 2003, 14:438-443.

3. Margeot A, Hahn-Hagerdal B, Edlund M, Slade R, Monot F: New improvements for lignocellulosic ethanol. Curr Opin Biotechnol 2009, 20:372-380.

4. Kersten P, Cullen D: Extracellular oxidative systems of the lignindegrading basidiomycete Phanerochaete chrysosporium. Fungal Genet Biol 2007, 44:77-87.

5. Martinez D, Larrondo LF, Putnam N, Gelpke MDS, Huang K, Chapman J, Helfenbein KG, Ramaiya P, Detter JC, Larimer F, Coutinho PM, Henrissat B, Berka R, Cullen D, Rokhsar D: Genome sequence of the lignocellulose degrading fungus Phanerochaete chrysosporium strain RP78. Nat Biotechnol 2004, 22:695-700.

6. Harreither W, Sygmund C, Dunhofen E, Vicuna R, Haltrich D, Ludwig R: Cellobiose dehydrogenase from the ligninolytic basidiomycete Ceriporiopsis subvermispora. Appl Environ Microbiol 2009, 75:2750-2757.

7. Li B, Nagalla SR, Renganathan V: Cloning of a CDNA encoding cellobiose dehydrogenase, a hemoflavoenzyme from Phanerochaete chrysosporium. Appl Environ Microbiol 1996, 62:1329-1335.

8. Moukha SM, Dumonceaux TJ, Record E, Archibald FS: Cloning and analysis of Pycnoporus cinnabarinus cellobiose dehydrogenase. Gene 1999, 234:23-33.

9. Roy BP, Dumonceaux T, Koukoulas AA, Archibald FS: Purification and characterization of cellobiose dehydrogenases from the white rot fungus Trametes versicolor. Appl Environ Microbiol 1996, 62:4417-4427.

10. Schmidhalter DR, Canevascini G: Isolation and characterization of the cellobiose dehydrogenase from the brown-rot fungus Coniophora puteana (Schum Ex-Fr) Karst. Arch Biochem Biophys 1993, 300:559-563.

11. Schou C, Christensen MH, Schulein M: Characterization of a cellobiose dehydrogenase from Humicola insolens. Biochem J 1998, 330:565-571.

12. Pricelius S, Ludwig R, Lant NJ, Haltrich D, Guebitz GM: Substrate specificity of Myriococcum thermophilum cellobiose dehydrogenase on mono-, 
oligo-, and polysaccharides related to in situ production of $\mathrm{H} 2 \mathrm{O} 2$. Appl Microbiol Biotechnol 2009, 85.

13. Zhang R, Fan Z, Kasuga T: Expression of cellobiose dehydrogenase from Neurospora crassa in Pichia pastoris and its purification and characterization. Protein Expr Purif 2010, 75(1):63-69.

14. Hallberg BM, Bergfors T, Backbro K, Pettersson G, Henriksson G, Divne C: A new scaffold for binding haem in the cytochrome domain of the extracellular flavocytochrome cellobiose dehydrogenase. Structure 2000, 8:79-88.

15. Dumonceaux TJ, Bartholomew KA, Charles TC, Moukha SM, Archibald FS: Cloning and sequencing of a gene encoding cellobiose dehydrogenase from Trametes versicolor. Gene 1998, 210:211-219.

16. Henriksson G, Sild V, Szabo IJ, Pettersson G, Johansson G: Substrate specificity of cellobiose dehydrogenase from Phanerochaete chrysosporium. Biochim Biophys Acta 1998, 1383:48-54.

17. Kremer SM, Wood PM: Production of Fenton reagent by cellobiose oxidase from cellulolytic cultures of Phanerochaete chrysosporium. Eur J Biochem 1992, 208:807-814.

18. Mason MG, Wilson MT, Ball A, Nicholls P: Oxygen reduction by cellobiose oxidoreductase: the role of the haem group. FEBS Lett 2002, 518:29-32

19. Samejima M, Eriksson KEL: A comparison of the catalytic properties of cellobiose: quinone oxidoreductase and cellobiose oxidase from Phanerochaete chrysosporium. Eur J Biochem 1992, 207:103-107.

20. Henriksson $G$, Johansson $G$, Pettersson $G$ : Is cellobiose oxidase from Phanerochaete chrysosporium a one-electron reductase? Biochim Biophys Acta 1993, 1144:184-190.

21. Igarashi K, Momohara I, Nishino T, Samejima M: Kinetics of inter-domain electron transfer in flavocytochrome cellobiose dehydrogenase from the white-rot fungus Phanerochaete chrysosporium. Biochem J 2002, 365:521-526

22. Baminger U, Subramaniam SS, Renganathan V, Haltrich D: Purification and characterization of cellobiose dehydrogenase from the plant pathogen Sclerotium (Athelia) rolfsii. Appl Environ Microbiol 2001, 67:1766-1774.

23. Dekker RFH: Cellobiose dehydrogenase produced by Monilia Sp. Meth Enzymol 1988, 160:454-463.

24. Nakagame S, Furujyo A, Sugiura J: Purification and characterization of cellobiose dehydrogenase from white-rot basidiomycete Trametes hirsuta. Biosci Biotechnol Biochem 2006, 70:1629-1635

25. Temp U, Eggert C: Novel interaction between laccase and cellobiose dehydrogenase during pigment synthesis in the white rot fungus Pycnoporus cinnabarinus. Appl Environ Microbiol 1999, 65:389-395.

26. Fang J, Liu W, Gao PJ: Cellobiose dehydrogenase from Schizophyllum commune: purification and study of some catalytic, inactivation, and cellulose-binding properties. Arch Biochem Biophys 1998, 353:37-46.

27. Subramaniam SS, Nagalla SR, Renganathan V: Cloning and characterization of a thermostable cellobiose dehydrogenase from Sporotrichum thermophile. Arch Biochem Biophys 1999, 365:223-230.

28. Vasil'chenko LG, Khromonygina W, Karapetyan KN, Vasilenko OV, Rabinovich ML: Cellobiose dehydrogenase formation by filamentous fungus Chaetomium sp. INBI 2-26(-). J Biotechnol 2005, 119:44-59.

29. Saha T, Ghosh D, Mukherjee S, Bose S, Mukherjee M: Cellobiose dehydrogenase production by the mycelial culture of the mushroom Termitomyces clypeatus. Process Biochem 2008, 43:634-641.

30. Yoshida M, Ohira T, Igarashi K, Nagasawa H, Samejima M: Molecular cloning and characterization of a CDNA encoding cellobiose dehydrogenase from the wood-rotting fungus Grifola frondosa. FEMS Microbiol Lett 2002, 217:225-230.

31. Henriksson G, Salumets A, Divne C, Pettersson G: Studies of cellulose binding by cellobiose dehydrogenase and a comparison with cellobiohydrolase 1. Biochem J 1997, 324:833-838.

32. Harreither W, Sygmund C, Augustin M, Narciso M, Rabinovich ML, Gorton L, Haltrich D, Ludwig R: Catalytic properties and classification of cellobiose dehydrogenases from Ascomycetes. Appl Environ Microbiol 2011, 77:1804-1815.

33. Henriksson G, Johansson G, Pettersson G: A critical review of cellobiose dehydrogenases. Journal of Biotechnology 2000, 78:93-113.

34. Westermark U, Eriksson KE: Purification and properties of cellobiose: quinone oxidoreductase from Sporotrichum pulverulentum. Acta Chemica Scandinavica Series B-Organic Chemistry and Biochemistry 1975, 29:419-424.
35. Ander P, Mishra C, Farrell RL, Eriksson KEL: Redox reactions in lignin degradation: Interactions between laccase, different peroxidases and cellobiose: quinone oxidoreductase. J Biotechnol 1990, 13:189-198.

36. Nutt A, Salumets A, Henriksson G, Sild V, Johansson G: Conversion of $\mathrm{O} 2$ species by cellobiose dehydrogenase (cellobiose oxidase) and glucose oxidase: a comparison. Biotechnol Lett 1997, 19:379-383.

37. Pricelius S, Ludwig R, Lant NJ, Haltrich D, Guebitz GM: In situ generation of hydrogen peroxide by carbohydrate oxidase and cellobiose dehydrogenase for bleaching purposes. J Biotechnol 2011, 6(2):224-230.

38. Henriksson G, Ander P, Pettersson B, Pettersson G: Cellobiose dehydrogenase (cellobiose oxidase) from Phanerochaete chrysosporium as a wood degrading enzyme. Studies on cellulose, xylan and synthetic lignin. Appl Microbiol Biotechnol 1995, 42:790-796.

39. Bao WJ, Renganathan V: Cellobiose oxidase of Phanerochaete chrysosporium enhances crystalline cellulose degradation by cellulases. FEBS Lett 1992, 302:77-80.

40. Langston JA, Shaghasi T, Abbate E, Xu F, Vlasenko E, Sweeney MD: Oxidoreductive cellulose depolymerisation by the enzymes cellobiose dehydrogenase and glycoside hydrolase 61. Appl Environ Microbiol 2011, 77(19):7007-7015.

41. Sigoillot C, Lomascolo A, Record E, Robert JL, Asther M, Sigoillot JC: Lignocellulolytic and hemicellulolytic system of Pycnoporus cinnabarinus: Isolation and characterization of a cellobiose dehydrogenase and a new xylanase. Enzyme Microb Technol 2002, 31:876-883.

42. Zamocky M, Hallberg M, Ludwig R, Divne C, Haltrich D: Ancestral gene fusion in cellobiose dehydrogenases reflects a specific evolution of GMC oxidoreductases in fungi. Gene 2004, 338:1-14.

43. Henriksson G, Pettersson G, Johansson G, Ruiz A, Uzcategui E: Cellobiose oxidase from Phanerochaete chrysosporium can be cleaved by papain into two domains. Eur J Biochem 1991, 196:101-106.

44. Eggert C, Temp U, Eriksson KEL: The ligninolytic system of the white rot fungus Pycnoporus cinnabarinus: purification and characterization of the laccase. Appl Environ Microbiol 1996, 62:1151-1158.

45. Stentelaire C, Lesage-Meessen L, Oddou J, Bernard O, Bastin G, Ceccaldi BC, Asther M: Design of a fungal bioprocess for vanillin production from vanillic acid at scalable level by Pycnoporus cinnabarinus. J Biosci Bioeng 2000, 89:223-230.

46. Eggert C, Temp U, Dean JFD, Eriksson KEL: Laccase-mediated formation of the phenoxazinone derivative, cinnabarinic acid. FEBS Lett 1995, 376:202-206.

47. Sigoillot C, Record E, Belle V, Robert JL, Levasseur A, Punt PJ, van den Hondel C, Fournel A, Sigoillot JC, Asther M: Natural and recombinant fungal laccases for paper pulp bleaching. Appl Microbiol Biotechnol 2004, 64:346-352.

48. Ohtakara A, Mitsutomi M, Uchida Y: Purification and enzymatic properties of alpha-galactosidase from Pycnoporus cinnabarinus. Agri Biol Chem 1984, 48:1319-1327.

49. Ohtakara A, Hayashi N, Mitsutomi M: Purification and some properties of acid beta-galactosidase from Pycnoporus cinnabarinus. J Ferment Techno 1981, 59:325-328.

50. Herpoel I, Moukha S, Lesage-Meessen L, Sigoillot JC, Asther M: Selection of Pycnoporus cinnabarinus strains for laccase production. FEMS Microbiol Lett 2000, 183:301-306.

51. Gnanamani A, Jayaprakashvel M, Arulmani M, Sadulla S: Effect of inducers and culturing processes on laccase synthesis in Phanerochaete chrysosporium NCIM 1197 and the constitutive expression of laccase isozymes. Enzyme Microb Technol 2006, 38:1017-1021.

52. Stapleton PC, O'Brien MM, O'Callaghan J, Dobson ADW: Molecular cloning of the cellobiose dehydrogenase gene from Trametes versicolor and expression in Pichia pastoris. Enzyme Microb Technol 2004, 34:55-63.

53. Yoshida M, Ohira T, Igarashi K, Nagasawa H, Aida K, Hallberg BM, Divne C, Nishino T, Samejima M: Production and characterization of recombinant Phanerochaete chrysosporium cellobiose dehydrogenase in the methylotrophic yeast Pichia pastoris. Biosci Biotechnol Biochem 2001, 65:2050-2057.

54. Conchie J, Gelman AL, Levvy GA: Inhibition of glycosidases by aldonolactones of corresponding configuration. Biochem J 1968, 106:135-40.

55. Parry NJ, Beever DE, Owen E, Vandenberghe I, Van Beeumen J, Bhat MK: Biochemical characterization and mechanism of action of a 
thermostable beta-glucosidase purified from Thermoascus aurantiacus. Biochem J 2001, 353:117-127.

56. Beeson WT, lavarone AT, Hausmann CD, Cate JHD, Marletta MA: Extracellular aldonolactonase from Myceliophthora thermophila. Appl Environ Microbiol 2010, 77(2):650-656.

57. Bruchmann EE, Schach H, Graf H: Role and properties of lactonase in a cellulase system. Biotechnol Appl Biochem 1987, 9:146-159.

58. Igarashi K, Tani T, Kawai R, Samejima M: Family 3 beta-glucosidase from cellulose-degrading culture of the white-rot fungus Phanerochaete chrysosporium is a glucan 1,3-beta-glucosidase. J Biosci Bioeng 2003, 95:572-576.

59. Yoshida M, Igarashi K, Kawai R, Aida K, Samejima M: Differential transcription of beta-glucosidase and cellobiose dehydrogenase genes in cellulose degradation by the basidiomycete Phanerochaete chrysosporium. FEMS Microbiol Lett 2004, 235:177-182.

60. Holtzapple M, Cognata M, Shu Y, Hendrickson C: Inhibition of Trichoderma reesei cellulase by sugars and solvents. Biotechnol Bioeng 1990, 36:275-287.

61. Strohdeicher M, Schmitz B, Bringermeyer S, Sahm H: Formation and degradation of gluconate by Zymomonas mobilis. Appl Microbiol Biotechnol 1988, 27:378-382.

62. van Dijken JP, van Tuijl A, Luttik MAH, Middelhoven WJ, Pronk JT: Novel pathway for alcoholic fermentation of delta-gluconolactone in the yeast Saccharomyces bulderi. J Bacteriol 2002, 184:672-678.

63. Tatum EL, Barrat RW, Frios N, Bonner D: Biochemical mutant strains of Neurospora produced by physical and chemical treatment. Am J Bot 1950, 37:38-46.

64. Couturier M, Haon M, Coutinho PM, Henrissat B, Lesage-Meesen L, Berrin JG: Podospora anserina hemicellulases potentiate Trichoderma reesei secretome for the saccharification of lignocellulosic biomass. Appl Environ Microbiol 2010, 77(1):237-246.

65. Laemmli UK: Cleavage of structural proteins during the assembly of the head of bacteriophage T4. Nature 1970, 227:680-5.

66. Bradford MM: Rapid and sensitive method for quantitation of microgram quantities of protein utilizing principle of protein-dye binding. Anal Biochem 1976, 72:248-254.

67. Tien M, Kirk TK: Lignin peroxidase of Phanerochaete chrysosporium. Methods Enzymol 1988, 161:238-249.

68. Paszczynski A, Huynh VB, Crawford R: Enzymatic activities of an extracellular, manganese-dependent peroxidase from Phanerochaete chrysosporium. FEMS Microbiol Lett 1985, 29:37-41.

69. Navarro D, Couturier M, da Silva GGD, Berrin JG, Rouau X, Asther M, Bignon C: Automated assay for screening the enzymatic release of reducing sugars from micronized biomass. Microb Cell Fact 2010, 9:58.

doi:10.1186/1475-2859-10-113

Cite this article as: Bey et al:. Heterologous expression of Pycnoporus cinnabarinus cellobiose dehydrogenase in Pichia pastoris and involvement in saccharification processes. Microbial Cell Factories 2011 10:113.

\section{Submit your next manuscript to BioMed Central and take full advantage of:}

- Convenient online submission

- Thorough peer review

- No space constraints or color figure charges

- Immediate publication on acceptance

- Inclusion in PubMed, CAS, Scopus and Google Scholar

- Research which is freely available for redistribution 